\title{
A Fragmentary Carrying Chair Scene in Salt Lake City, Utah
}

\author{
EDWARD BROVARSKI
}

\begin{abstract}
In the collections of the Utah Museum of Fine Arts in Salt Lake City is a fragmentary limestone relief of a chair carrying scene. The relief fragment in Salt Lake City was a gift to the museum from Natacha Rambova (née Shaugnessy), a dancer, spiritualist, Hollywood costume and set designer, and one-time wife of Rudolph Valentino, who developed an interest in ancient Egypt. Such chair carrying scenes in the Old Kingdom are generally accompanied by a porters' ditty, a so-called Sänftenlied. The fragmentary scene in Salt Lake City is unusual in substituting commands to the porters for the ditty.
\end{abstract}

Keywords: carrying chair scene, 'Sänftenleid', Natasha Rambova, Utah Museum of Fine Arts, Metjetji, Pepy I

Edward Brovarski, Brookline, Massachusetts; edward.brovarski@verizon.net

In the collections of the Utah Museum of Fine Arts in Salt Lake City is a fragmentary limestone relief showing seven porters carrying the chair of an Old Kingdom noble (Figs 1-2). The relief bears the accession number UMFA 1958.001. That this is indeed part of a chair carrying scene is clear from the attitude of the bearers, whose arms are raised to support the pole of the chair. In front of and behind them are the figures of two officials who are giving commands to the porters. The unusual content of their speeches will be discussed further below.

Only a small portion of the foremost official survives. He may or may not have had his head turned back to address the porters. The forward portion of the body of the rearmost official is preserved. He raises his arm in a gesture of address. ${ }^{1}$ It is clear that both officials wore a short kilt with a projecting front panel. This is apparent in the first instance from the segment of selvedge preserved on the official's kilt.

The porters of the chair are wigless and have their hair close-cropped. For modesty's sake, they are wearing a long belt sash whose loose ends hang down in front.

\footnotetext{
${ }^{1}$ Müller 1937: 69-70, Fig. 10.
} 
The carrying chair was a sign of high social rank and importance. ${ }^{2}$ The motif of the tomb owner transported in a carrying chair or a more elaborate palanquin recurs in a fair number of tombs of Old Kingdom date, beginning with a portrayal in the tomb of prince Nefermaat at Medum in the early Fourth Dynasty. ${ }^{3}$ Written evidence suggests that the use of a carrying chair was a privilege granted by the king, who also assigned youths of the Residence to carry the chair. Carrying chairs were used for visits and inspections of every sort. ${ }^{4}$

The relief fragment in Salt Lake City was a gift to the museum from Natacha Rambova (née Shaugnessy), a dancer, spiritualist, Hollywood costume and set designer, and onetime wife of Rudolph Valentino, who developed an interest in ancient Egypt. Having studied briefly under S.R.K. Glanville and met Alexandre Piankoff, she recorded religious texts in the royal tombs under the latter's direction and helped with the publication of the texts in the Bollingen series. ${ }^{5}$ The former director of the Utah Museum of Fine Arts, Mr. Sanguinetti, talked with Rambova before her death, but she kept no accession records, and he was unable to gather much information from her (Letter August 2, 1982 from William Balken, Registrar). Thus, the original provenance of the Utah chair carrying scene relief is unknown.

An anonymous gallery label of which Mr. Balken kindly sent me a copy suggests the tomb of Niankh-nesut as a possible provenance, although no other fragments of such a scene are known to have survived from his tomb. ${ }^{6}$ It occurs to me that another possible source might be the tomb of Metjeti. A fragment of limestone relief from the latter tomb that shows the upper part of a chair carrying scene at present resides in the Virginia Museum of Fine Arts (acc. no. 55.6.2) in Richmond, Virginia. ${ }^{7}$ It is nevertheless difficult to envision a join between the Richmond and Salt Lake City fragments because one is damaged at the bottom and the other at the top. In support of the putative join is that both pieces are in medium-high relief of good quality and both have extensive traces of paint. If the fragment indeed comes from the tomb of Metjetji, it would date to the first half of the Sixth Dynasty, since Metjetji seemingly served Pepy I in office. ${ }^{8}$

\section{INSCRIPTION}

The speech on the left seemingly reads as follows:

'Iry nfr! 'Thr! Hr.k m tpt- ${ }^{\circledR} w y . k$

Do well! Be calm! Your face straight ahead of you.

${ }^{2}$ Goedicke 1959: 9.

${ }^{3}$ Petrie 1892: P1. 21.

${ }^{4}$ Brovarski 1996: 134-135.

${ }^{5}$ Bierbrier (Ed.) 2012: 154, 431-432.

${ }^{6}$ Leahy, Mathieson 2001: 33-42.

${ }^{7}$ Kaplony 1976: no. 2.

${ }^{8}$ Brovarski 2010: 85-139. 


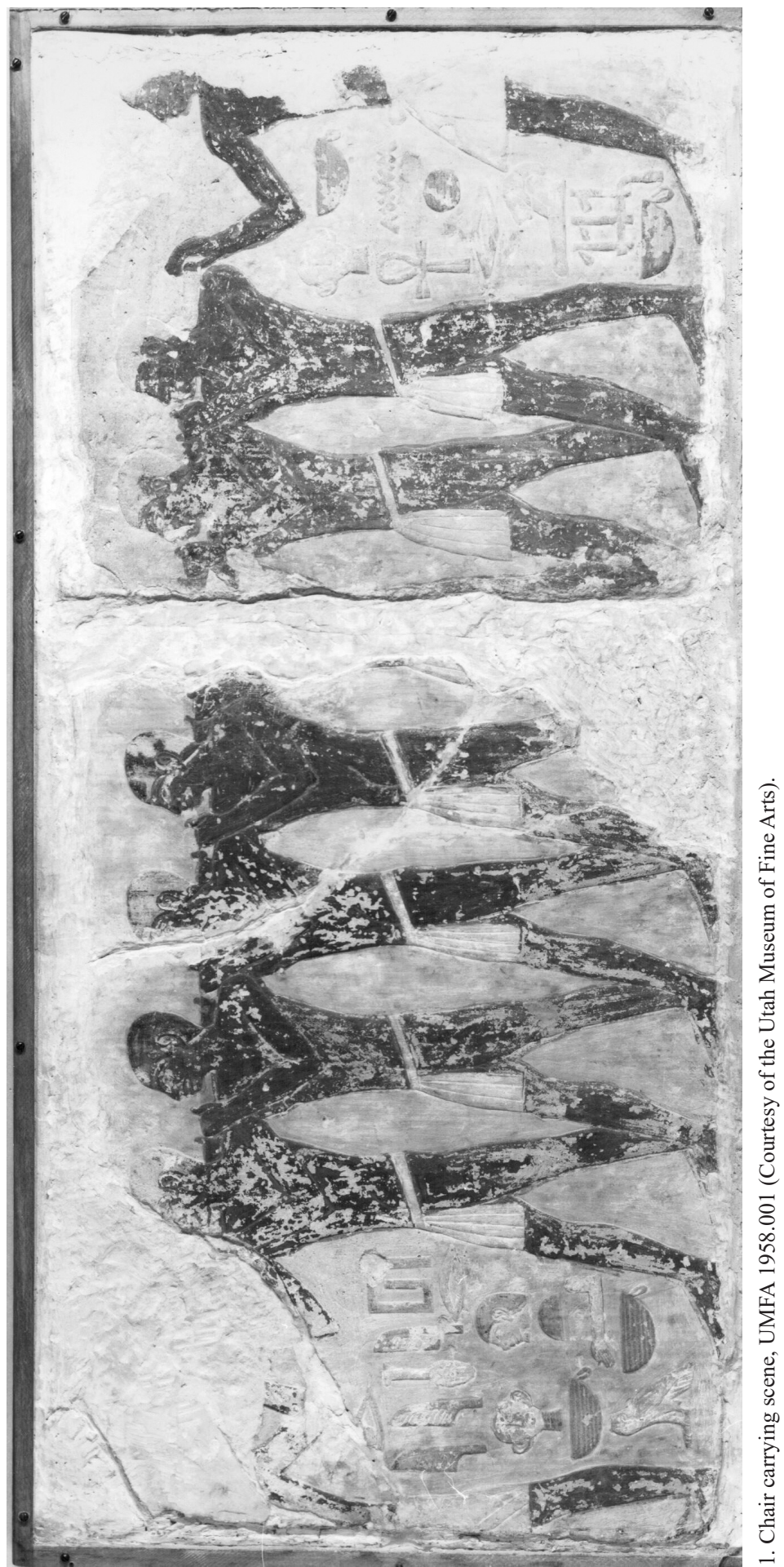




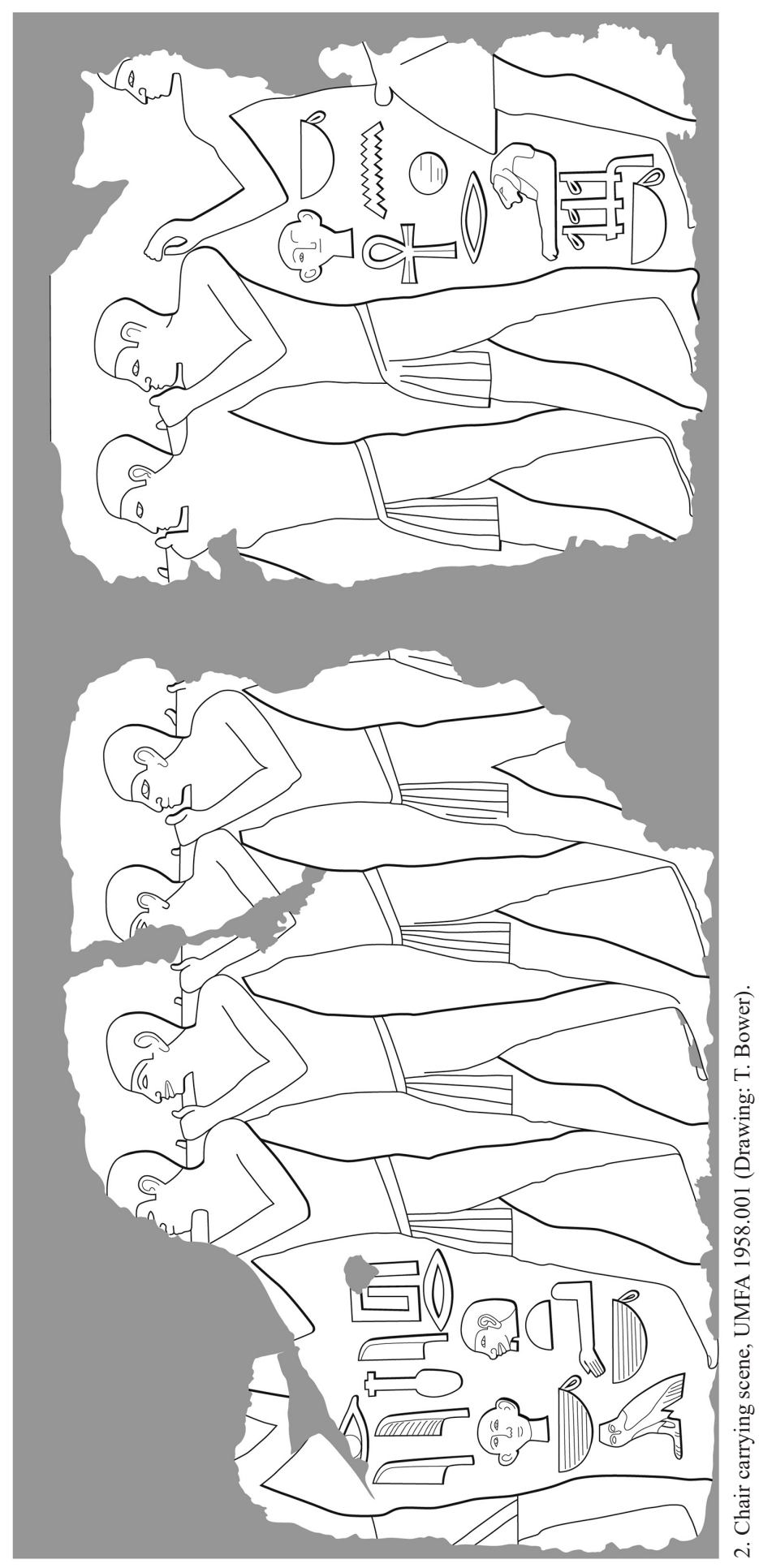




\section{COMMENTARY}

a) Note that E. Edel (1955: $\S 602)$, lists imperative $(w) d j$ with a single or a double reed leaf under the heading of third weak and irregular verbs. The writing of $(w) d j$ alternately as imperative $d j$ and $d j j$ provides a clue to the reading of $j r j j$ as an imperative form, even though Edel (1995: § 602), lists only three possibilities for that form of $j r j: j r, j r(r)$, and jrj (with a single read leaf).

b) For imperative $j h r$ with prothetic $-j$, see: Edel 1955: $\S 602$.

c) The verb $h r$ means 'be statisfied, be calm, be peaceful, rejoice'; see: AnLex 2: 232 (78.2510); Hannig 2003: 751 [19068].

d) Hr.k $m$ tpt- ${ }^{-} w y . k$, recurs in the tomb of In-sneferu-ishtef at Dahshur (Morgan 1903: 19-21 = Borchardt 1964: 190, P1. 102). For $m$ tpt- ${ }^{\top} w y . k$, see: $W b$ VI, 284 (12).

e) 'wy is written with the arm with palm downwards, which is regularly employed for the dual; see: Fischer 1996: 180-186.

Given that the speech on the left is a command, it is logical that the right-hand speech would be also.

$h r . k^{\top} n h(w) r-h ̧ 3(t) s 3 h . k$,

Be vigilant to the front of your feet (lit. 'toe')!

\section{COMMENTARY}

a) The construction is a subject stative with $h r . k{ }^{\complement} n h(w)$ a nominal subject with a following third person singular stative. The translation of the phrase evidently is: 'Your face lives', that is, 'Be vigilant!'. Edel 1964: $\$ 906 b b$, in fact, provides a close parallel to $h r . k{ }^{\top} n h(w)$ in the chapel of Kai-em-rehu in Copenhagen (Mogensen 1921). For the relationship between the stative and the imperative, see: Edel 1955: 5992.

b) Hannig 2003: 761 [19454] provides references to both $r-h 3(t)$ and $j r-h 3 t$ with the meanings 'nach vorn' and 'vorwärts.'

c) For s3h, 'toe', see: Lefebvre 1952: 59; Hannig 2003: 1066 [26025].

Chair carrying scenes in the Old Kingdom are generally accompanied by a porters' ditty, a so-called Sänftenlied, which has been discussed at some length by H. Altenmüller. ${ }^{9}$ The fragmentary scene in Salt Lake City is unusual in substituting commands to the porters for the ditty. In fact, to my knowledge, it is unique in this regard.

\footnotetext{
${ }^{9}$ Altenmüller 1984: 7-14; 1984-1985: 15-30.
} 


\section{Acknowledgments}

The existence of the relief was pointed out to me by Mr. Lynn H. Holden some years ago, for which I thank him. I would also like to express my appreciation to Mr. William Balken, Register of the Utah Museum of Fine Arts in 1982, for the photograph of the relief reproduced here and permission to publish it.

\section{References}

Altenmüller, H. 1984: Sokar im Alten Reich und der Wind, GöttMisz 78, 7-14

Altenmüller, H. 1984-1985: Das 'Sänftenleid' des Alten Reiches, BSEG 9-10, 15-30

Bierbrier, M. (Ed.) 2012: Who Was Who in Egyptology, London

Borchardt, L. 1964: Catalogue général des antiquités égyptiennes du Musée du Caire, Nos 1295-1808: Denkmäler des Alten Reiches (Ausser den Statuen) II, Le Caire

Brovarski, E. 1996: An Inventory List from "Covington's Tomb" and Nomenclature for Furniture in the Old Kingdom, [in:] Der Manuelian, P., Freed, R.E. (Eds), Studies in Honor of William Kelly Simpson I, Boston, 117-155

Brovarski, E. 2010: The Date of Metjetji, [in:] Hawass, Z., Wegner, J.H. (Eds), Millions of Jubilees: Studies in Honor of David P. Silverman I, ASAE-Suppl. 39, Le Caire, 85-139

Edel, E. 1955: Altägyptische Grammatik I, AnOr 34, Roma

Edel, E. 1964: Altägyptische Grammatik II, AnOr 39, Roma

Fischer, H.G. 1996: Varia Nova, Egyptian Studies III, New York

Goedicke, H. 1959: A Fragment of a Biographical Inscription of the Old Kingdom, JEA 45, $8-11$

Honig, R. 2003: Ägyptisches Wörterbuch I: Altes Reich und Erste Zwischenzeit, Hannig-Lexica 4, Kulturgeschichte der antiken Welt 98, Mainz a/Rhein

Kaplony, P. 1976: Studien zum Grab des Methethi, Monographien der Abegg-Stiftung Bern 8, Bern

Leahy, A., Mathieson, I. 2001: The Tomb of Nyankhnesut (Re)Discovered, JEA 87, 33-42

Lefebvre, G. 1952: Tableau des parties du corps humain mentionées par les Égyptiens, ASAE-Suppl. 17, Le Caire

Mogensen, M. 1921: Le mastaba égyptien de la Glyptotèque Ny Carlsberg, Copenhague Morgan, J. de 1903: Fouilles à Dahchour en 1894-1895, Vienne

Müller, H. 1937: Darstellungen von Gebärden auf Denkmälern des Alten Reiches, MDAIK 7 , 57-118

Petrie, W.M.F. 1892: Medum, London 


\section{ÉTUDES et TRAVAUX XXX / 2017}

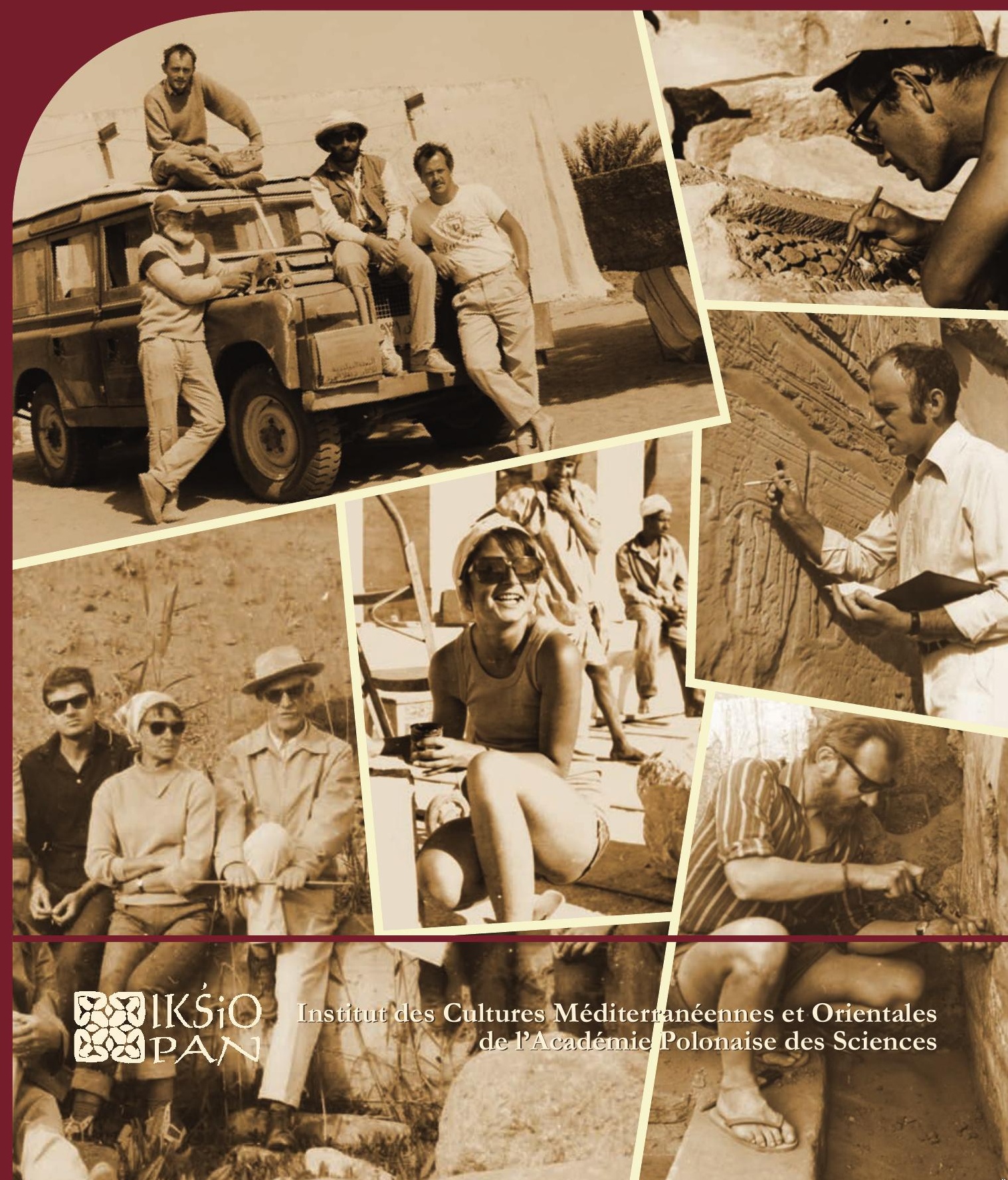




\title{
COMITÉ DE RÉDACTION SCIENTIFIQUE
}

Maciej Makowski - rédacteur en chef

Jadwiga Iwaszczuk - rédacteur et sécretaire de la rédaction

Mariusz Drzewiecki - rédacteur

Maciej G. Witkowski - rédacteur

\section{CONSEIL SCIENTIFIQUE DU JOURNAL}

M. Kobusiewicz (IAE PAS, Warszawa), E. Laskowska-Kusztal (IMOC PAS, Warszawa),

D. Michaelides (University of Cyprus, Nicosia),

J.Ch. Moretti (IRAA-MOM, Université de Lyon 2/CNRS),

D. Raue (Ägyptisches Museum der Universität Leipzig), P. Reynolds (ICREA, Barcelona),

D. Welsby (British Museum, London)

\section{COMITÉ SCIENTIFIQUE DE LECTURE}

J. Holaubek (Institut für Ägyptologie, Wien), S. Ikram (AUC, Cairo),

K. Innemée (Universiteit Leiden), J. McKenzie (Faculty of Oriental Studies, University of Oxford),

N. Strudwick (University of Cambridge), A. Loprieno-Gnirs (Universität Basel),

Ch.E. Loeben (Museen für Kulturgeschichte, Hannover), Y. Tristant (Macquarie University, Sydney),

V.W.J. van Gerven Oei (University of Aberdeen), A. Peignard-Giros (HiSoMA-MOM, Université de Lyon 2/CNRS), J.A. Ostrowski, E. Papuci-Władyka, J. Śliwa (IA JU, Kraków), R. Czerner (WUST, Wrocław), A. Ćwiek (IA AMU, Poznań), M. Wiewióra (IA NCU, Toruń), K. Domżalski

(IAE PAS, Warszawa), K.O. Kuraszkiewicz (DE FOS UW), M. Barwik, P. Bieliński, P. Dyczek, W. Godlewski, D. Ławecka, S. Rzepka, J. Żelazowski, M. Gawlikowski, J. Młynarczyk, A. Niwiński, T. Sarnowski, D. Szeląg, T. Waliszewski (IA UW, Warszawa)

\section{RÉDACTEUR THÉMATIQUE DU VOLUME \\ Barbara Lichocka}

\author{
AIDE RÉDACTION TECHNIQUE \\ Dorota Dobrzyńska, Mariusz Drzewiecki
}

REVUE DES TEXTES ANGLAIS

Jo Harper 
ÉTUDES et TRAVAUX XXX 
INSTYTUT KULTUR ŚRÓDZIEMNOMORSKICH I ORIENTALNYCH POLSKIEJ AKADEMII NAUK

\section{STUDIA i PRACE}

XXX

\section{Ro IKŚSiO \\ ESA PAN}

WARSZAWA

2017 
INSTITUT DES CULTURES MÉDITERRANÉENNES ET ORIENTALES DE L'ACADÉMIE POLONAISE DES SCIENCES

\section{ÉTUDES et TRAVAUX}

XXX

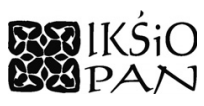

VARSOVIE

2017 
Publication scientifique financée dans le cadre du programme du Ministre de la Science et de l'Éducation Supérieure

« Programme National de Développement de l’Humanistique » pour les années 2016-2021 (projet no 3bH 150099 83)

\title{
HARODOWY PROGRAM ROZWOJU HUMANISTYKI
}

\author{
Copyright (C) \\ Instytut Kultur Śródziemnomorskich i Orientalnych PAN \\ et les Auteurs \\ Warszawa 2017
}

\author{
ISSN 2084-6762 \\ (avant $2011: 0079-3566$ ) \\ e-ISSN 2449-9579 \\ Version première en papier, imprimée en Pologne - 150 copies \\ Version électronique accessible sur \\ http://www.etudesettravaux.iksiopan.pl
}

Édition: Polskie Towarzystwo Historyczne et Wydawnictwo Neriton, Warszawa

Conception générale de couverture : J. Iwaszczuk

Photos de couverture : En haut, à gauche. Vieille Dongola 1991, S. Jakobielski

(debout à gauche), K. Pluskota (debout à droite), B. Żurawski (assis sur le camion)

et P. Wierzbicki (assis sur le camion) (de la collection de B. Żurawski)

En haut, à droite. Palmyre 1964, M. Marciniak au travail (phot. A. Dziewanowski)

Au centre. E. Laskowska-Kusztal au travail (de la collection de E. Laskowska-Kusztal)

En bas, à gauche. Tell Atrib 1962 ; de gauche : T. Biniewski, M. Marciniak, K. Kołodziejczyk,

K. Michałowski, A. Ostrasz, S. Jakobielski et S. Jasiewicz devant eux

(de la collection de IKŚSiO PAN).

En bas, à droite. Vieille Dongola 1976, S. Jakobielski nettoyant le mur (phot. M. Steinborn).

Au centre, à droite, K. Myśliwiec en train des travaux de documentation (de la collection de IKŚiO PAN) 


\section{Table des matières}

BARBARA LICHOCKA

Ergon agathon

Hartwig Altenmüller

$\mathrm{Zu}$ den Feindbildern auf den Zauberstäben des Mittleren Reiches und der Zweiten

Zwischenzeit

Nathalie Beaux

Des $m s w n s w$ de Thoutmosis III à Deir el-Bahari

Briant Bohleke, Nigel Strudwick

A Label for Opening of the Mouth Implements from the Burial of Senneferi (TT99)

and Remarks on the Ritual

Rosa Maria Bonacasa Carra, Nicola Bonacasa

Nuovi dati sugli edifici termali di Sabratha

EDWARD BROVARSKI

A Fragmentary Carrying Chair Scene in Salt Lake City, Utah

Julia Burdajewicz

Wall Painting Decoration from the North-West Church in Hippos-Sussita

of the Decapolis

Mariusz BURDAJEWICZ

From Pagan Temple to Church in Late Antiquity Palestine. A View from

Hippos-Sussita

MAREK ChlodNicki

Early Dynastic Bead Workshops at the Central Kom of Tell el-Farkha.

Patryk ChudziK, Mariusz Caban

Observations on the Architecture of the Tomb of Horhotep in Western Thebes

Krzysztof M. Cialowicz

New Discoveries at Tell el-Farkha and the Beginnings of the Egyptian State.

Amr EL-TiebI

Four Wooden New Kingdom Female Statuettes in the Egyptian Museum, Cairo 


\section{Naguib KanaWATI}

Ritual Marriage Alliances and Consolidation of Power in Middle Egypt during the Middle Kingdom

Adam Łajtar, Jolanta Mlynarczyk

A Faction Acclamation Incised on a Pithos Found Near the North-West Church at Hippos (Sussita)

Adam ŁaJTAR, Grzegorz OchaŁa

Two Private Prayers in Wall Inscriptions in the Faras Cathedral

Adam Łajtar, Anna Poludnikiewicz

Medicinal Vessels from Tell Atrib (Egypt)

JaCeK Michniewicz, Jolanta MlynarczyK

Petrographic Variability of the Fabrics of Wine Jars from Sha'ar-Ha Amakim as a Reflection of Differences in Their Provenance and Chronology

Iwona ModrzewsKa-PianetTI

Les importations d'amphores Dressel 20 en Gaule Cisalpine

Arthur SEgal

Samaria-Sebaste. Portrait of a polis in the Heart of Samaria 409

JOACHIM ŚLIWA

The Motif of a 'Blind Harper' in an Unexpected Place

MONIKA WIĘCH

Searching for the Kitchen in the Early Roman Phase of the 'Hellenistic' House at Nea Paphos (Cyprus)

Abréviations 
THE VOLUME IS PUBLISHED TO CELEBRATE

THE $60^{\text {TH }}$ ANNIVERSARY

OF THE ESTABLISHMENT OF

THE RESEARCH CENTRE FOR MEDITERRANEAN ARCHAEOLOGY POLISH ACADEMY OF SCIENCES

FOUNDED IN 1956

WHOSE MISSION IS CONTINUED BY

THE INSTITUTE OF MEDITERRANEAN AND ORIENTAL CULTURES

OF THE POLISH ACADEMY OF SCIENCES 